Vol. 1, No. 1, 2020

Roman Kachmar, Olena Lanets

Lviv Polytechnic National University

Bandery Str. 12, Lviv, Ukraine, 79000

(C) Kachmar R., Lanets O., 2020

https://doi.org/10.23939/tt2020.01.083

\title{
THE IMPACT OF PARAMETERS OF TRAFFIC FLOWS OF LVIV STREET-ROAD NETWORK ON THE LEVEL OF ENVIRONMENTAL AND ECONOMIC LOSSES
}

\begin{abstract}
Summary. The analysis of directions and effectiveness of various methods of examining the impact of the urban street-road network on the level of eco-pollution was carried out with the use of the method of determining environmental and economic losses from changes in traffic flow indicators. The method of estimating the environmental damage dynamics due to harmful emissions of vehicles was applied. On the basis of conducted researches, practical recommendations were developed for such variants: prohibition of private transport motion on the road section, increasing the amount of electric transport, reducing the average age of vehicles to the accepted European level.
\end{abstract}

Key words: road transport, traffic flow indicators, traffic and pedestrian flow, emission of toxic components.

\section{INTRODUCTION}

Today there is a difficult situation within large cities and industrial regions in Ukraine. Up to $90 \%$ of the total level of atmospheric pollution is the emissions of pollutants from road transport. [1]. The operation of road transport is accompanied by a strong negative impact on all environmental components, especially the atmospheric air.

The increased negative influence of products of the impact of road transport is caused by the growth rate of the car's number, especially imported into the country in transit, the technical condition of which don't meet the requirements of the European Union as well as the requirements of the current legislation of Ukraine [2]. The problem is the relatively higher toxicity of emissions from mobile sources than from stationary sources and the inability to develop ways of protecting against pollution by the exhaust gases of road transport on the way of their spreading. Moreover, the pollutants themselves are placed spatially directly in residential areas [3].

The assessment of the environmental hazard by a traffic flow is usually performed on the basis of determining the harmfulness of the emissions of their exhaust gases, taking into account traffic composition, the main characteristics of the traffic flow, as well as the specific emission indicators for each type of vehicle under different driving conditions.

Ukraine has declared the transition to sustainable development with further improvement of the of environmentally balanced development of the entire motor transport complex. Particularly important is the organizational and economic principle of the environmental section of the motor transport complex. At this stage of development of the structure of the motor transport complex the priority is [4]:

- arranging of monitoring of pollution and pollution sources, determination of pollution levels of all components and resources of the natural environment and identification of the most dangerous places for human health; 
- assessment of negative impacts on human and ecosystems regarding the maximum permissible and critical levels of pollution and anthropogenic loads, as well as developing criteria for the acceptability and criticality of these impacts on various elements of the biosphere and human;

- assessment of environmental, economic, social and aesthetic damage caused to the environment by pollution and degradation;

- forecast of the dynamics of anthropotechnogenic impacts and loads on the biosphere, as well as the estimation of the negative consequences arising from this.

\section{RESEARCH STATEMENT}

In general, the impact of the motor vehicle complex causes significant environmental damage, which can be expressed in terms of economic indicators. Recently, the use of the term "green economy", which has a material component of the impact of anthropogenic activities due to human activity, has become popular. At the same time, it should be emphasized that today it is impossible to assess the damage to human and society accurately from the point of view of economics, the impact is determined by known average methods and coefficients.

There is a problem of estimating changes in the environmental impact of traffic flows, depending on traffic flow indicators, changes in traffic patterns or planning decisions, etc. Therefore, the main task of the research is to develop a model for determining the level of environmental and economic losses caused by changes in traffic flow indicators to estimate the dynamics of environmental damage due to harmful vehicle emissions.

\section{FORMULATION OF THE PROBLEM}

A number of scientists are holding the research to determine the environmental indicators of traffic flows and the car, in particular, Yu. F. Hutarevych [5], V. P. Mateychyk [6], O. V. Pryimachenko [7], $\mathrm{Yu}$. S. Shevchenko [8]. At the same time, none of them determined the overall vehicle environmental performance of various types and designs by determining the level of exhausted gas toxins emission depending on various factors and adjusting parameters as well as the produced noise level.

In recent years, in Lviv the work has been intensively underway to restore the cover of the road network. In most cases, projects are funded with the assistance of the European Bank for Reconstruction and Development, in particular, a large amount of credit is provided for the implementation of projects for partial modernization of the transport infrastructure of Lviv, with Lviv municipal enterprises "Lvivelectrotrans" and "Lvivavtodor". At the same time, it should be noted that the projects of modernization of the transport infrastructure are implemented in accordance with the requirements of the technical documentation for the road network, but at the same time do not take into account the peculiarities of changing the environmental load on the section of the road network after reconstruction or modernization. At the same time, Lviv municipal enterprise "Spatial Development Institute", which develops projects, pays great attention to giving advantages and preferences to public transport and bicycle transport in traffic. [9]. Today, there isn't any project for the reconstruction of the streets of Lviv, which is being approved if a separate bike lane in the street after the reconstruction is not predicted. Also, it is mandatory to install individual bike lanes when rebuilding sidewalks and pedestrian paths.

In general, there is a clear gradation of the priority of moving in the city of Lviv, a pedestrian is in the first place, then the next is public transport, then there is bicycle traffic and it is a private transport in the last place. It is a trend to manage traffic in the European contingent when private transport meets many obstacles to motivate owners of it to use public transport, which will reduce traffic flows as well as reduce ecological pressures on the environment $[10,11]$.

In process of new routes designing or applying different measures or reconstructing existing roads, it is necessary to take into account the change in traffic flow indicators and determine their impact on the environment, considering changes in traffic flow parameters, depending on changes in traffic flow speed, traffic flow composition, electro vehicles and an average age of vehicles, ratio in the flow of vehicles with 
gasoline and diesel engines and the number of drivers, passengers, pedestrians and building inhabitants that are adversely affected by the exhaust gases of car engines.

\section{RESEARCH METHODOLOGY}

It is offered to use the methodology of Prof. Yu. A. Vrubel [12], with the aim of establishing both the change in the mass emission of toxic components from the exhaust gases of cars and the estimated level of economic losses from the emission of harmful substances into the atmosphere. With this aim, it is necessary to calculate the cost of environmental damage from the total emissions $\left(M_{0}\right)$ and the human health damage from the consumer-reduced amount of emissions $\left(M_{i}\right)$.

The annual loss on a linear object is determined by the formula [12]:

$$
P_{A}=\left[M_{0} \cdot C_{m o}+\sum_{1}^{i=3}\left(N_{i} \cdot C_{m i}\right)\right] \cdot T_{y} \cdot S \cdot K_{C}, \text { units/year, }
$$

where $M_{0}$ - specific amount of generated emissions, $\mathrm{kg} / \mathrm{km} ; C_{m o}$ - the cost of environmental losses of $1 \mathrm{~kg}$ emission reduced to CO pollutants, $C_{m o}=0.025$ units $/ \mathrm{kg}$ [12]; $N_{i}$ - specific number of consumers of this category, persons $/ \mathrm{km} ; C_{m i}$ - the cost of the environmental loss per person during the hour of harmful substances at a concentration equivalent to the specific reduced emission volume $M_{i}$, units/person.; $T_{y}-$ annual time fund, h/year; $S$ - length of the segment, km; $K_{C}$ - social coefficient of environmental losses. formula:

The specific amount of emissions generated by the movement of a vehicle is determined by the

$$
M_{0}=Q^{*} \cdot m \cdot\left[K_{d}\left(K_{m v} \cdot K_{i v}-1\right)+H_{t} \cdot K_{m v} \cdot K_{i v}\right], \mathrm{kg} / \mathrm{km},
$$

where $Q^{*}$ - calculated traffic intensity, vehicle $/ \mathrm{h} ; m$ - fundamental (minimum) value reduced to CO summarized emissions of the passenger vehicle, $\mathrm{kg} / \mathrm{km}$ (in the absence of other information, it is accepted $m=0.02 \mathrm{~kg} / \mathrm{km}[12]) ; K_{d}$ - the dynamic coefficient of reduction of traffic flows is accepted $K_{d}=1.12$; $K_{m v}$ - coefficient of change of emissions from speed (Fig. 1); $K_{i v}$ - coefficient of change of emission from speed dispersion; $H_{t}$ - vehicle age coefficient [12].

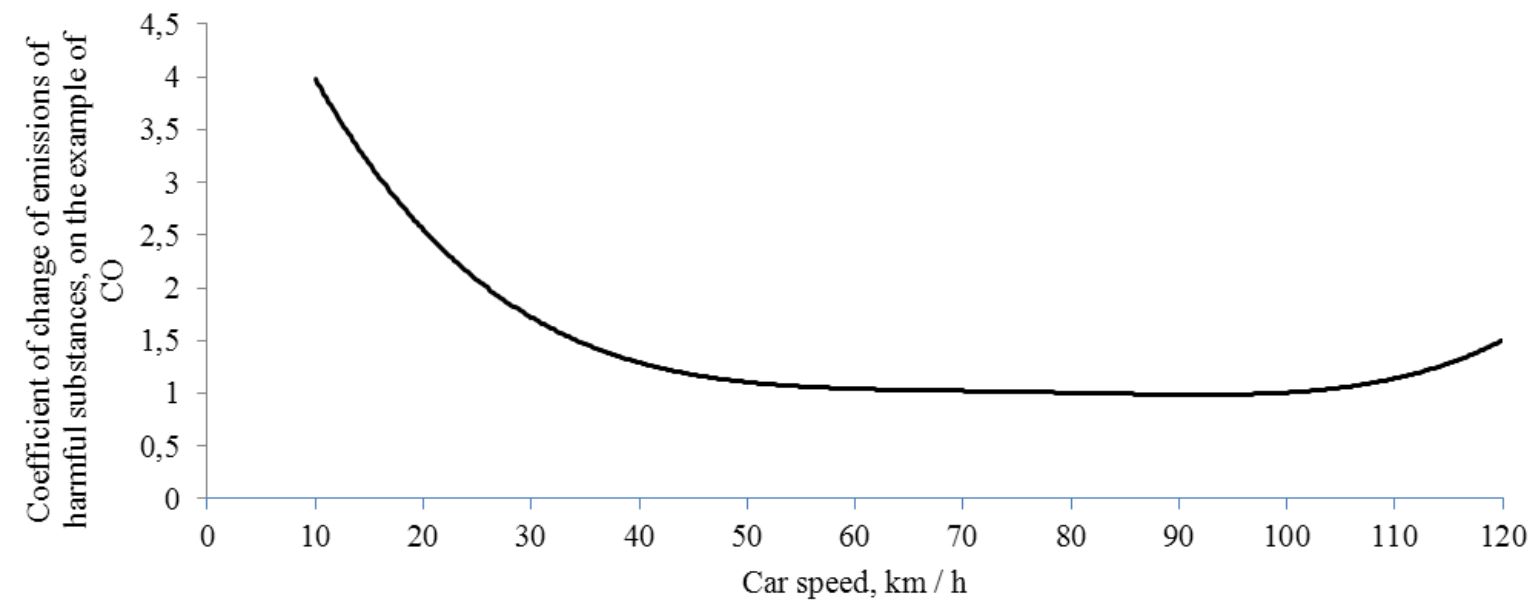

Fig. 1. The dependence of the emission change coefficient $K_{\mathrm{m}}$ on the speed of an average kind of a car [13]

The calculated traffic intensity $Q^{*}$ is determined by:

$$
Q^{*}=Q\left[1-\Delta_{e l}\left(1+K_{e l}-K_{d}\right)\right] \text {, vehicle } / h,
$$

where $Q$ - traffic flow intensity, vehicle/h (it is considered the total traffic flow which parameters are defined as the average values of the input flow parameters); $\Delta_{\theta I}$ - part of electric transport in traffic flow; $K_{e l}$ - the dynamic coefficient of reduction of electric transport $K_{e l}=2 ; K_{d}$-dynamic coefficient of traffic flow reduction $K_{d}=1.12$. 
The age coefficient of a vehicle is determined taking in account its composition [12]:

$$
H_{t}=\Delta_{g} \cdot K_{d g} \cdot K_{t g}+\Delta_{d} \cdot K_{d d} \cdot K_{t d},
$$

where $\Delta_{g}, \Delta_{d}$ - respectively, the part in the flow of vehicles with gasoline and diesel engines; $K_{d g}, K_{d d}-$ respectively, the dynamic coefficient of reduction of vehicles with gasoline and diesel engines; $K_{t g}, K_{t d}-$ respectively, the emission coefficient by the age of vehicles with gasoline and diesel engines is determined by taking into account the average age of the vehicle [12].

Specific number of consumers in this category, determined for three groups affected by traffic flows:

- drivers and passengers $N_{1}$;

- pedestrians $N_{2}[12]$

- inhabitants of adjacent buildings $N_{3}$.

The number of drivers and passengers affected by traffic flows is determined by:

$$
N_{1}=\frac{(\Delta O \cdot 40+1.5) \cdot Q}{V}, \text { persons } / \mathrm{km},
$$

where $\Delta O$ - part of public transport in the flow; $Q$ - traffic intensity, vehicle/h; $V$ - the speed of movement, $\mathrm{km} / \mathrm{h}$;

Item $N_{2}$ is determined by [12]:

$$
N_{2}=\frac{Q_{n}}{V_{n}}, \text { persons } / \mathrm{km},
$$

where $Q_{n}$ - total, including sidewalk and pedestrian crossing, pedestrian traffic flow intensity, persons/h; $V_{n}$ - pedestrian speed, $\mathrm{km} / \mathrm{h}, V_{n}=4 \mathrm{~km} / \mathrm{h}$ - sidewalks, $V_{n}=5 \mathrm{~km} / \mathrm{h}$ - pedestrian crossing.

For detailed calculations, the number of $N_{3}$ should be given in the output data, but it may differ for the calculation of losses from emission.

For approximate calculations, depending on the type and purpose of the building, can be accepted:

$$
N_{3}=(0,7 \ldots 1,0) \cdot N_{\text {win }} \text {, persons } / \mathrm{km} \text {, }
$$

where $N_{\text {win }}$ - specific (per $1 \mathrm{~km}$ ) number of roadside windows (up to $50 \mathrm{~m}$ ) facing the road, windows $/ \mathrm{km}$.

The cost of environmental damage per person during the hour of harmful substances at a concentration equivalent to the specific reduced volume of emissions is determined by:

$$
C_{m i}=0.005 \sqrt{M_{i}-6}, \text { unit/person, }
$$

where $M_{i}$ - the equivalent specific reduced (to the consumer) volume of emission from traffic flow, $\mathrm{kg} / \mathrm{km}$.

3 consumer categories are examined: drivers and passengers (1), pedestrians (2) and inhabitants of adjacent buildings (3).

It is accepted that:

- drivers [12]:

$$
M_{1}=M_{0} \cdot K_{Z 1}, \mathrm{~kg} / \mathrm{km},
$$

where $K_{Z 1}-$ driver and passenger protection coefficient, it is accepted $K_{Z 1}=1[12]$;

- pedestrians [12]:

$$
M_{2}=M_{0} \cdot K_{Z 2}, \mathrm{~kg} / \mathrm{km},
$$

where $K_{Z 2}$ - pedestrian protection coefficient:

$$
K_{Z 2}=e^{-0.04\left(r_{2}+5 \cdot i_{2}\right)},
$$

where $r_{2}$ - distance from the middle of the trajectory of the nearest row of traffic flow movement to the middle of the sidewalk, $\mathrm{m} ; i_{2}$ - the number of rows of trees and bushes that effectively protect pedestrians from environmental impact.

If the roadway and sidewalks are regularly and effectively cleaned, then this can be equated to some (up to 1) number of plantings; 
- inhabitants of adjacent buildings [12]:

where $K_{Z 3}-$ resident protection coefficient [12]:

$$
M_{3}=M_{0} \cdot K_{Z 3}, \mathrm{~kg} / \mathrm{km},
$$

$$
K_{Z 3}=e^{-0.04\left(r_{3}+5 \cdot i_{3}+10\right)},
$$

where $r_{3}$ - the distance (diagonally) from the middle of the trajectory of the nearest row of traffic flow movement to the average height building windows, $\mathrm{m}$.

The height of the building can be approximately determined by the formula [12]:

$$
0.5 \cdot H \approx 3 \cdot n_{f}+2, m
$$

where $n_{f}$ - number of floors of the building; $i_{3}$ - the number of rows of trees (and bushes for single-story buildings) that effectively protect pedestrians from emission impact, with the presence of protective structures, the number of rows $i_{3}$ can be slightly increased.

The dependence of the emission factor $K_{m v}$ on the speed of an average kind of car is illustrated in (Fig. 1) [13]. It is determined by the expression:

$$
K_{i v}=\sqrt{1+I_{v}}
$$

where $I_{v}$ - the coefficient of variation of the distribution of the transport flow speed, it is accepted $I_{v}=0.1$.

\section{DETERMINATION OF ENVIRONMENTAL AND ECONOMIC DAMAGE}

S. Bandera Street, as typical for the central part of Lviv, was chosen for the research of changes in environmental and economic indicators of traffic flows dependent on their characteristics. The method of estimation of the dynamics of environmental damage due to the impact of harmful cars emissions was used in researches. The street is one of the main thoroughfares of the city and carries a heavy traffic load. There are 4 tram and 8 bus routes along the street with intensive general traffic flow, as well as quite an intensive pedestrian traffic since near 900-1000 people pass along each side of the street.

Since the Department of Sustainable Transportation Systems of Lviv Municipal Enterprise "Institute for Spatial Development" has planned the reconstruction of S. Bandera Street, then in 2018 specialists of Lviv Polytechnic National University conducted the research of transport and pedestrian flows characteristics and determined their indicators. The research was commissioned by "Institute for Spatial Development" (Fig. 2) [14].

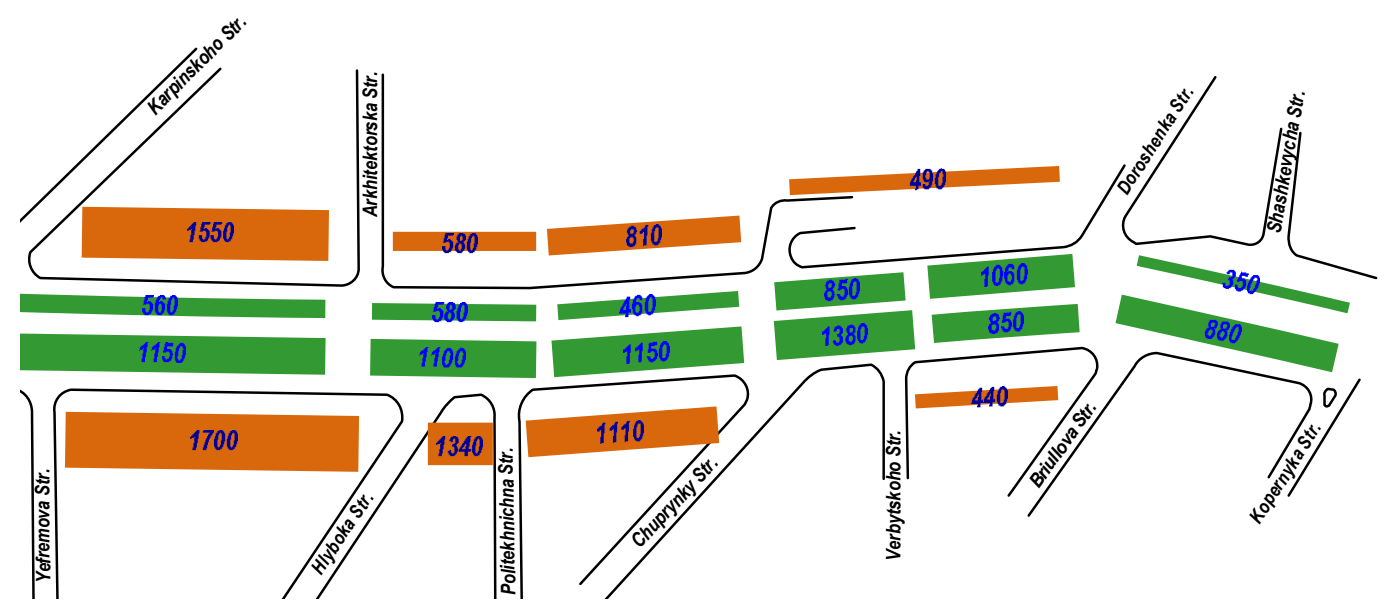

Fig. 2. Section of S. Bandera street indicating hourly traffic and pedestrian flow on its segments [14]

The results of the determination of traffic and pedestrian flow indicators at the examined street were taken for the determination of environmental and economic indicators from changes in traffic characteristics. The total length of the $1300 \mathrm{~m}$ road was divided into segments. 
For the first segment of the street, from Kopernyka to Bryullov Street (see Fig. 2), the maximum total pollution from traffic flow is observed at the speed of $5 \mathrm{~km} / \mathrm{h}$ and it is $275.8 \mathrm{~kg} / \mathrm{km}$ per hour. Then the calculation of economic losses according to the formula (1), taking into account the annual time fund, the damage will be 151.4 thousand UAH per year. In the second segment, from Bryullov to Verbytskyi Street, at the same speed of $5 \mathrm{~km} / \mathrm{h}$, the total pollution is estimated at $436.38 \mathrm{~kg} / \mathrm{km}$ per hour, which will amount to damage of 64.1 thousand UAH per year. Such a low value is explained by the small length of the street segment and the absence of buildings on one side of the street.

For the last, eleventh segment of the street, from Fedkovycha to Horodotska Street, at a speed of $5 \mathrm{~km} / \mathrm{h}$ total pollution per hour is $256.3 \mathrm{~kg} / \mathrm{km}$, or 79.3 thousand UAH per year of economic damage. This area is of most interest because, according to the plans of the Institute for Spatial Development, the movement of private transport will be forbidden here.

The environmental losses indicators from the impact of traffic flow for other segments of the street are similarly determined.

According to the results of the calculation of the level of environmental and economic damage, depending on changes in the characteristics of the traffic flow, both the specific hourly emission of toxic components (Fig. 3a) and the loss from exhaust gases of vehicles on the entire section of S. Bandera Street are determined by the proposed method (Fig. 3b).

$a$

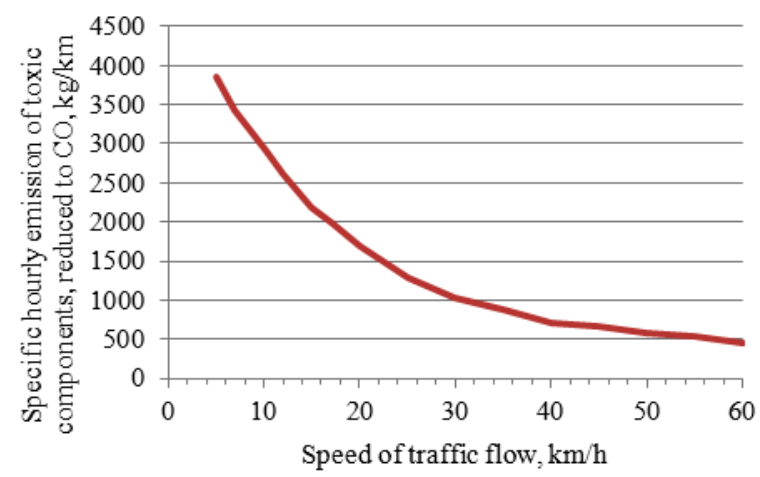

$b$

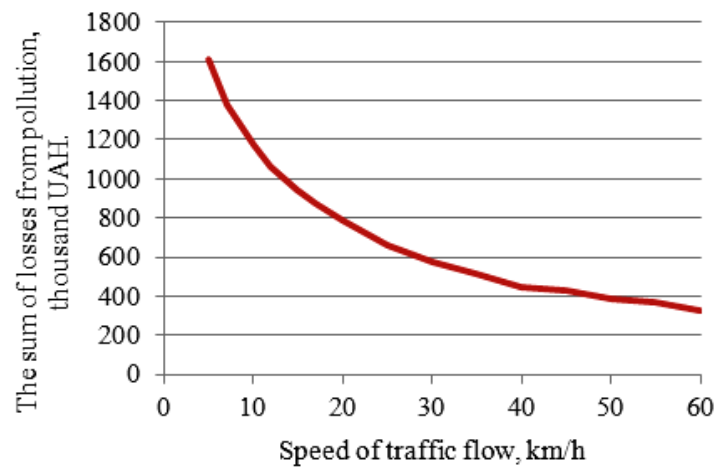

Fig. 3. Change of specific hourly emission of toxic components (a) and loss from the exhaust gases of vehicles (b) depending on the speed of vehicles on the whole section of S. Bandera Street

There is a clear reduction of environmental losses with increasing vehicle speed on the entire flow speed range, in particular, an increase of flow speed from 5 to $50 \mathrm{~km} / \mathrm{h}$, will lead to a reduction of hourly emissions from 3.8 to $0.46 \mathrm{t} / \mathrm{km}$ changing the environmental losses quantities from the impact of traffic flow from 1.6 to 0.3 million UAH per year.

It should be noted that the average speed of traffic in the cities of Ukraine as well as in major European cities is usually slightly lower and it is in the range of $12-21 \mathrm{~km} / \mathrm{h} \mathrm{[15].} \mathrm{Such} \mathrm{a} \mathrm{low-speed} \mathrm{value}$ is due to the high traffic delays, when in the coordinating system of traffic lights regulation, the priority is given to route buses and pedestrian flows. Particular preference is given to route buses which move on purposed lanes, thus providing a significant advantage to such vehicles and reducing their delay time.

\section{POSSIBLE WAYS TO REDUCE ENVIRONMENTAL LOSSES}

Let's examine possible ways of environmental losses reduction from the impact of traffic flow, depending on the traffic speed in S. Bandera Street. To reduce environmental losses from the impact of traffic flow in S. Bandera Street the following measures were considered :

- prohibition of private transport motion on the road section;

- increasing the amount of electric transport;

- reducing the average age of vehicles to the accepted European level. 
The calculation of the environmental losses from the influence of traffic flow was held, depending on the speed of traffic in S. Bandera Street, taking into account the proposal of the Institute for Spatial Development, namely, the possible prohibition of the movement of private transport on the road section of Kropyvnytskyi Square. When applying such a measure as a prohibiting of the movement of private transport on the area of Kropyvnytskyi Square, then the level of environmental load in S. Bandera Street will be reduced to $4.1 \%$ at the entire traffic speed diapason. In absolute values, such prohibiting will allow to reduce emissions per hour by 156.3 or $23.7 \mathrm{~kg} / \mathrm{km}$ at the respective speeds of 5 and $50 \mathrm{~km} / \mathrm{h}$.

The increase of electric vehicles number in the streets of Ukrainian cities, a law prolonging the possibility of free-of-tax import of electric vehicles to Ukraine for another four years signed by the President, allowed to design how the number of cars in the traffic flow would affect street pollution. Previously, the methodology stated that every hundredth car is an electric vehicle, that is why the environmental losses from the impact of traffic flow depending on the traffic speed in S. Bandera Street were determined when using electric cars, provided that every tenth car is an electric vehicle.

It was obtained that the reduction of the level of environmental load in S. Bandera Street will range from $10.2 \%$ to $4.3 \%$ at the respective traffic speeds of 5 and $50 \mathrm{~km} / \mathrm{h}$.

Today more than 9.1 million cars are registered in Ukraine, $53.4 \%$ of which are cars manufactured in the former USSR and post-Soviet countries. In Ukraine, about $20 \%$ of cars had been produced before 1985, the most of these cars are VAZ, GAS, ZAZ, as well as modern Volkswagen, Daewoo, Ford, Opel [16]. It should be emphasized that this number does not include cars imported in transit, which is up to $1.5-2$ million cars according to various estimates.

It was determined that the average age of vehicles, officially registered in Ukraine based on statistics, is 19.6 years [17]. Therefore, the calculations of environmental efficiency were carried out for this value.

It was made an attempt to determine the relative reduction of the environmental load in S. Bandera Street in the condition of the average age of cars reduction, for example, up to 10 years (Fig. 4).

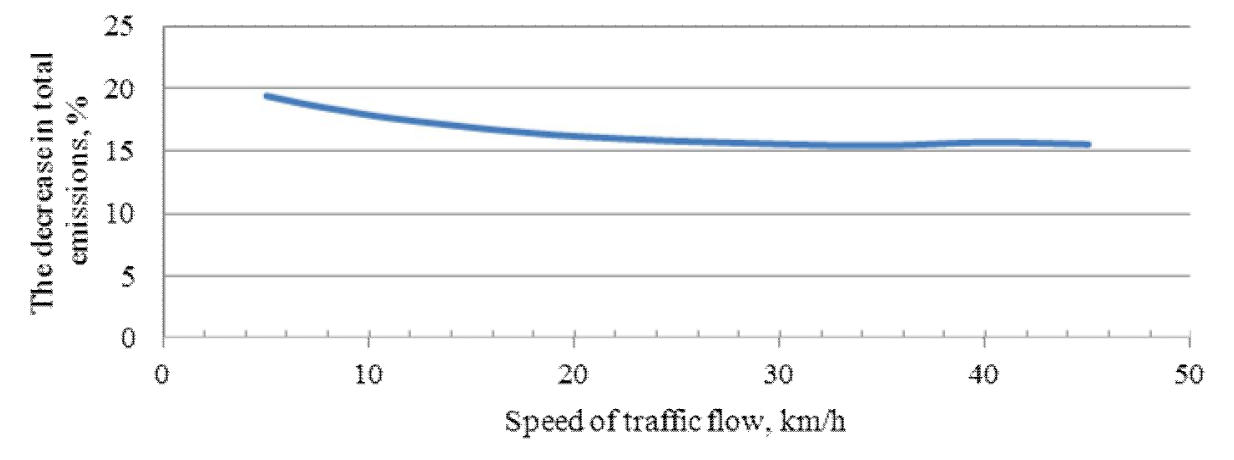

Fig. 4. Relative reduction of the level of environmental lo ad in S. Bandera Street provided the average age of cars is reduced to 10 years

Obviously, with a reduction of the average age of cars up to 10 years, a relative decrease in the level of environmental load in the street will be above $15 \%$ in the entire speed range of cars along S. Bandera Street.

\section{CONCLUSIONS:}

1. The calculation of the level of environmental and economic damage, depending on the speed of traffic flow showed that changing the flow speed rate from 5 to $50 \mathrm{~km} / \mathrm{h}$ will reduce the hourly emissions from 3.8 to $0.46 \mathrm{t} / \mathrm{km}$.

2. When applying the prohibition on private traffic on a section of the road, in particular, the prohibition of the movement of private transport in Kropyvnytskyi Square, this will reduce the level of environmental load in the entire S. Bandera Street, which will account for $4.1 \%$ on the entire transport flow speed rate. 
3. It was determined that increasing the number of electric vehicles from $1 \%$ to $10 \%$ will lead to a decrease of the level of environmental load, on the example of S. Bandera Street, range from $10.2 \%$ to $4.3 \%$ at the speed of 5 and $50 \mathrm{~km} / \mathrm{h}$, respectively.

\section{References}

1. González, C. M., Gómez, C. D., Rojas, N. Y., Acevedo, H., \& Aristizábal, B. H. (2017). Relative impact of on-road vehicular and point-source industrial emissions of air pollutants in a medium-sized Andean city. Atmospheric environment, Volume 152, 279-289 (in English).

2. Kachmar R. Ya., Lanets' O. S., Pelekh V. P. (2018). Otsinyuvannya vplyvu zminy pokaznykiv transportnykh potokiv na riven' yikh ekolohichnoho navantazhennya [Evaluation of the impact of traffic flow indicators change on the level of ecological loading]. Teoriya ta praktyka ratsional'noho proektuvannya, vyhotovlennya $i$ ekspluatatsiyi mashynobudivnykh konstruktsiy : materialy 6-oyi Mizhnarodnoyi naukovo-tekhnichnoyi konferentsiyi (L'viv, 25-26 zhovtnya 2018 r.) ( pp. 111-113). (in Ukrainian).

3. Cheruiyot, N. K., Lee, W. J., Yan, P., Mwangi, J. K., Wang, L. C., Gao, X. et al. (2016). An overview of $\mathrm{PCDD} / \mathrm{F}$ inventories and emission factors from stationary and mobile sources: What we know and what is missing. Aerosol Air Qual. Res, Volume 16, 2965-2988 (in English).

4. Trehobchuk V. (2002). Kontseptsiya staloho rozvytku dlya Ukrayiny [A concept of sustainable development for Ukraine]. Visnyk natsional'noyi akademiyi nauk Ukrayiny [Visnyk of the national science academy of Ukraine], Volume 2, 31-40. (in Ukrainian).

5. Hutarevych, Yu. F., Shuba, Ye. V., Syrota, O. V., \& Trifonov, D. M. (2019). Vplyv dobavky vodnevmisnoho hazu na ekolohichni pokaznyky dvyhuniv z iskrovym zapaliuvanniam v rezhymakh kholostoho khodu [Influence of hydrogen gas additive on environmental performance of spark-ignition engines in idle]. Visnyk Natsional'noho transportnoho universytetu [The National Transport University Bulletin: A Scientific and Technical Journal], Volume 1, 39-48. (in Ukrainian).

6. Mateychyk, V. P., Tsyuman, M. P., \& Smeshek, M. (2016). Osoblyvosti monitorynhu i kontrolyu pokaznykiv ekolohichnoyi bezpeky transportnykh zasobiv i transportnykh potokiv $\mathrm{v}$ umovakh intelektualnykh system [Pecularities of the monitoring and control of indicators of ecological safety of vehicles and traffic flows in conditions of intelligent systems]. Visnyk Natsional'noho transportnoho universytetu, Volume 1, 255-266. (in Ukrainian).

7. Pryymachenko O. V. (2013). Vplyv mahistralnykh vulyts na ekolohichnyy stan mizhmahistralnykh terytoriy [Impact of arterial streets on ecological state of interarterial territories]. Mistobuduvannya ta terytorialne planuvannya [Urban planning and territorial planning], Volume 48, 355-358 (in Ukrainian).

8. Shevchenko, Yu. S. (2016). Development of the models of evaluation and the increase of the effectiveness of traffic flow noise reduction. Candidate's thesis. Kyiv: NAU (in Ukrainian).

9. LKP Instytut ptostorovoho rozvytku [LCE Institute of Spatial Development]. Retrieved from https://cityadm.lviv.ua/lmr/utilities/lkp-instytut-prostorovoho-rozvytku. (in Ukrainian).

10. Kachmar R., Vasyuhnyk J. (2017). Operational conditions of vehicles motion and formation of urban driving cycle in the city of Lviv. Ukrainian Journal of Mechanical Engineering and Materials Science. Volume 3, 117-124 (In English).

11. J. Fornalchyk, R. Kachmar. (2010). Selective assessment of environmental side of traffic in Lviv. Energetic and ecological aspects of agricultural production. Faculty of Production Engineering Warsaw University of Life Sciences (pp. 59 - 66). Warsaw (Poland). (In English)

12. Vrubel' Yu. A. (2003). Poteri v dorozhnom dvizhenii [Losses in traffic movement]. Minsk: BNTU (in Russian).

13. Solukha I. B. (2015). Vplyv shvydkosti rukhu avtomobil'noho transportu na vykydy zabrudnyuyuchykh rechovyn $\mathrm{v}$ atmosferne povitrya [Impact of speed of movement of automotive transport on the emissions of harmful substances into the air]. Suchasni problemy arkhitektury ta mistobuduvannya [Modern problems of the architecture and urban planning] Volume 39, 242-247. (in Ukrainian).

14. U Lvovi proponuiut obmezhyty rukh transportu na chastyni vulytsi Bandery: yak tse bude (vizualizatsia) [It is proposed to restrict the traffic movement on the section of Bandery Street in Lviv: how it will be (visualization)]. 
Retrieved from https://www.032.ua/news/1810625/u-lvovi-proponuut-obmeziti-ruh-transportu-na-castini-vulicibanderi-ak-ce-bude-vizualizacia. (in Ukrainian).

15. Sitovs'kyy O. P., Kashuba A. M. (2012). Vyznachennya parametriv rukhu avtomobilya v dorozhnikh zatorakh [Determination of the parameters of vehicle movement in traffic jams]. Visnyk SevNTU - Visnyk of SevNTU, Volume 135, 134-137. (in Ukrainian).

16. Skolko eurobliakh v Ukraine i chto s nimi delat [How much "eurobliakh" are there in Ukraine and what to do with them]. Retrieved from https://ukranews.com/publication/2280-skolko-evroblyakh-v-ukrayne-y-chto-s-nymydelat.

17. Serednii vik avtomobiliv v Ukraini perevushchue 20 rokiv [The average age of the vehicles in Ukraine exceeds 20 years] Retrieved from https://tsn.ua/ukrayina/seredniy-vik-avtomobiliv-v-ukrayini-perevischuye-20-rokiv1146537.html.

Received 03.03.2020; Accepted in revised form 30.03.2020. 